\title{
Microfilaments, microtubules and intermediate filaments fulfil differential roles during gonadotropin-induced expansion of bovine cumulus oophorus
}

\author{
P Šutovský ${ }^{1 \#, ~ J E ~ F l e ́ c h o n ~}{ }^{2 *}$, A Pavlok ${ }^{1}$ \\ 1 Institute of Animal Physiology and Genetics, Czech Academy of Sciences, \\ 27721 Libéchov, Czech Republic; \\ 2 INRA, Laboratoire de Biologie Cellulaire et Moléculaire, 78350 Jouy-en-Josas, France
}

(Received 12 April 1994; accepted 4 July 1994)

\begin{abstract}
Summary - The relationship between cytoskeleton and morphology of cumulus granulosa cells in expanding bovine oocyte-cumulus complexes (OCCs) cultured in vitro has been investigated by the means of indirect immunofluorescence and transmission electron microscopy. The round-shaped cells in unstimulated control OCCs displayed a homogeneous distribution of cytoskeletal networks and cytoplasmic organelles. Luteinizing hormone $(\mathrm{LH})$ stimulation caused the redistribution of microfilaments (MFs), accelerated the development of Golgi apparatus, and led to the generation of lipid droplets in cumulus cells. These changes culminated in the elongation and polarization of cumulus cells and in the extension of the cytoplasmic networks of microtubules (MTs) and intermediate filaments (IFs) into the newly formed cyloplasmic projections. The culture of OCCs in the presence of microfilament disruptor cytochalasin B prevented cumulus expansion, formation of cellular projections and cell elongation and suppressed the development of the Golgi apparatus. On the contrary, cytochalasin had no effect on the abundance and distribution of lipid droplets and on the integrity of IFs and MTs. The present data support the hypothesis that the response of cumulus granulosa cells to $\mathrm{LH}$ is partially mediated by F-actin.
\end{abstract}

cumulus expansion / oocyte maturation / cytoskeleton / F-actin / tubulin / vimentin

Résumé - Les microfilaments, les microtubules et les filaments intermédiaires jouent des rôles différents pendant l'expansion du cumulus oophorus bovin induit par les gonadotropines. Les rapports entre le cytosquelette et la morphologie des cellules de la granulosa dans les complexes ovocytes cumulus (OCCs) bovins cultivés in vitro ont été analysés à l'aide des techniques d'immunofluorescence et de microscopie électronique à transmission. Dans les OCCs témoins non

\footnotetext{
* Correspondence and reprints.

\# Present address: University of Wisconsin, Department of Zoology, 1117, West Johnson Street, Madison, WI 53706, USA
} 
expansés, les cellules arrondies montrent une distribution homogène du cytosquelette et des organites cellulaires. La stimulation par l'hormone lutéinisante $(L H)$ provoque la redistribution des microfilaments (MFs), le développement de l'appareil de Golgi et le dépôt de gouttelettes lipidiques dans les cellules du cumulus. Ces modifications aboutissent à l'élongation et à la polarisation des cellules et à l'extension des réseaux de microtubules (MTs) et de filaments intermédiaires (IFs) dans les nouvelles projections cytoplasmiques. La culture d'OCCs, en présence de cytochalasine $B$ qui bloque la polymérisation des microfilaments, empêche l'expansion du cumulus, la formation de projections cytoplasmiques et l'élongation cellulaire et inhibe le développement de l'appareil de Golgi. Au contraire, la cytochalasine n'a pas d'effet sur l'accumulation et la distribution de gouttelettes lipidiques ni sur l'intégrité des IFs et des MTs. Les résultats obtenus sont en faveur d'une transmission partielle par l'actine $F$ de la réponse à la $L H$ des cellules du cumulus oophorus.

expansion du cumulus / maturation ovocytaire / cytosquelette / actine F/ tubuline / vimentine

\section{INTRODUCTION}

The expansion of cumulus oophorus seems to be a necessary preliminary step for the release of matured mammalian oocytes from ovarian follicles (Dekel et al, 1979). Until now, cumulus expansion has been considered as a consequence of the increased synthesis and deposition of hyaluronic acidrich extracellular matrix by the innermost population of granulosa cells, termed cumulus cells. This has been supposed to cause the volumetric enlargement of cumulus oophorus, the spatial isolation of cells from one another, and the interruption of transport pathway between oocytes and somatic follicle cells (Eppig, 1980; Larsen et al, 1986). Consequently, meiotic resumption has been explained by the cessation of the uptake of granulosa cell-generated inhibitory molecules into the oocyte, due to the downregulation of cumulus cell gap junctions (Larsen et al, 1987).

In contrast with these findings, the recent studies of Allworth and Albertini (1993) and Sutovsky et al (1993) demonstrated that the $\mathrm{LH}$-induced expansion of bovine cumulus oophorus involved dramatic cytoskeletal rearrangement, gradually affecting all the cytoskeletal components of cumulus cells including microfilaments (MFs), intermediate filaments (IFs) and microtubules (MTs). Moreover, the preovulatory rearrangement of gap junctions seems to have no effect on the efficiency of gap junctional communication between the cells of the expanded cumulus oophorus (Šutovský et al, 1993). The involvement of the cytoskeleton in cumulus expansion is supported by the finding that the microfilament disruptor dihydrocytochalasin B or its analogues cytochalasin $B$, cytochalasin $D$, inhibit cumulus expansion (Wert and Larsen, 1989). These facts may be related to the hypothesis that the effect of $\mathrm{LH}$ on granulosa cells in vitro is partially mediated by F-actin (Ben Ze'ev and Amsterdam, 1989).

The present work is aimed at deducing the relationship between the reorganization of the cytoskeleton and the process of cumulus cell differentiation throughout the period of cumulus expansion in vitro. The present data provide evidence that individual cytoskeletal components play differential roles during cumulus expansion and support the idea that $\mathrm{F}$-actin is involved in the transduction of $\mathrm{LH}$-induced signals inside cumulus cells.

\section{MATERIALS AND METHODS}

\section{Isolation and in vitro culture of bovine oocyte-cumulus complexes}

Bovine ovaries were collected at a local slaughterhouse and used for isolation of oocyte-cumu- 
lus complexes (OCCs) from large antral follicles 2-8 $\mathrm{mm}$ in diameter. Part of OCCs were cultured for up to $24 \mathrm{~h}$ in modified M199 culture medium (Pavlok et al, 1992), supplemented with $10 \%$ fetal calf serum (Flow Laboratories) $\pm 0.4 \mathrm{mg} / \mathrm{ml} \mathrm{LH}$. The other part of OCCs was cultured in the above culture medium with addition of $5-20 \mathrm{mg} / \mathrm{ml}$ of cytochalasin B. The culture was carried out at $39^{\circ} \mathrm{C}$ in a humid atmosphere enriched by $5 \%$ $\mathrm{CO}_{2}$. Freshly isolated OCCs and OCCs withdrawn from culture at intervals of $3 \mathrm{~h}$ were processed for immunofluorescence or electron microscopy.

We will term the cells from freshly isolated OCCs at time 0 (to) unstimulated cumulus cells. The results were the same with OCCs cultured without LH (data not shown).

\section{Immunofluorescence}

The OCCs were fixed for $20 \mathrm{~min}$ in $2.5 \%$ paraformaldehyde dissolved in washing medium (phosphate-buffered saline, ph 7.3), treated for $1 \mathrm{~h}$ with a solution of $50 \mathrm{mM}$ ammonium chloride to eliminate free aldehydic groups, rinsed and conserved in washing medium containing $0.05 \%$ sodium azide and $1 \mathrm{mM}$ phenylmethylsulfonyl fluoride. A 2-step indirect immunocytochemical procedure including saponin permeabilization was applied as described previously (Šutovský et al, 1993). To visualize the Golgi apparatus, we used the anti-Golgi CTR433 mouse monoclonal antibody recognizing a Triton $X-100$ extractable antigen of the medium compartment in the Golgi (Jasmin et al, 1989). This antibody, kindly provided by M Bornens (CNRS, Gif-sur-Yvette, France), was diluted to 1:5. MTs were visualized by TU 01 mouse monoclonal antibody (Viklický et al, 1982), diluted 1:20. This was kindly provided by $V$ Viklický (Institute of Molecular Genetics, Praha, Czech Republic). This antibody recognizes bovine $\alpha$-tubulin (Dráber ef al, 1986). An anti-vimentin mouse monoclonal antibody (Sigma, Saint Louis, MO; diluted 1:200), given as highly specific for bovine cells, was used for the visualization of IFs. Negative controls were obtained by the omission of all the first antibodies. The microfilaments were labelled by rhodamine-conjugated phalloidin (Molecular Probes, Eugene, OR). The oocyte nuclear maturation was assessed by staining cumulus-free oocytes with Hoechst $33258(5 \mu \mathrm{g} / \mathrm{ml})$. The OCCs were exam- ined and photographed with a fluorescence microscope (Polyvar-Reichert Jung or Orthoplan-Leitz).

\section{Electron microscopy}

The OCCs were fixed for $1 \mathrm{~h}$ in a mixture composed of $0.6 \%$ paraformaldehyde and $2.5 \%$ glutaraldehyde in PBS, postfixed in $1 \%$ osmium tetroxide, dehydrated by ethanol, perfused and embedded in Epon 812 (Serva, Heidelberg, Germany). Epon blocks with the samples were cut with the ultramicrotome Reichert-Jung Ultracut $E$, contrasted by uranyl acetate and lead citrate and observed with a Jeol 1200 EX electron microscope.

\section{RESULTS}

\section{Effect of LH stimulus and cytochalasin B on the morphology of bovine cumulus granulosa cells}

The round-shaped cumulus cells in the unstimulated (t0) OCCs displayed a homogeneous constitution of the cytoplasm, containing large mitochondria, rough endoplasmic reticulum (RER) and rare lipid droplets (fig 1A, B). Numerous small microvilli were found at the surface of these cells (fig 1A). A 24-h culture in the presence of $\mathrm{LH}$ induced the expansion of cumulus oophorus and the extension of intercellular spaces. The cells acquired an elongated shape, characterized by the polarization of cytoplasm and the formation of a large radially oriented cellular projections (fig 1C). These projections contained mainly bundles of IFs and MTs (fig 1D), but the opposite cytoplasmic pole was generally occupied by large clusters of lipid droplets, a well-developed Golgi apparatus and abundant RER profiles (fig 1E, 4C). This development of the Golgi apparatus has also been demonstrated by immunofluorescent labelling with the CTR433 antibody. In con- 

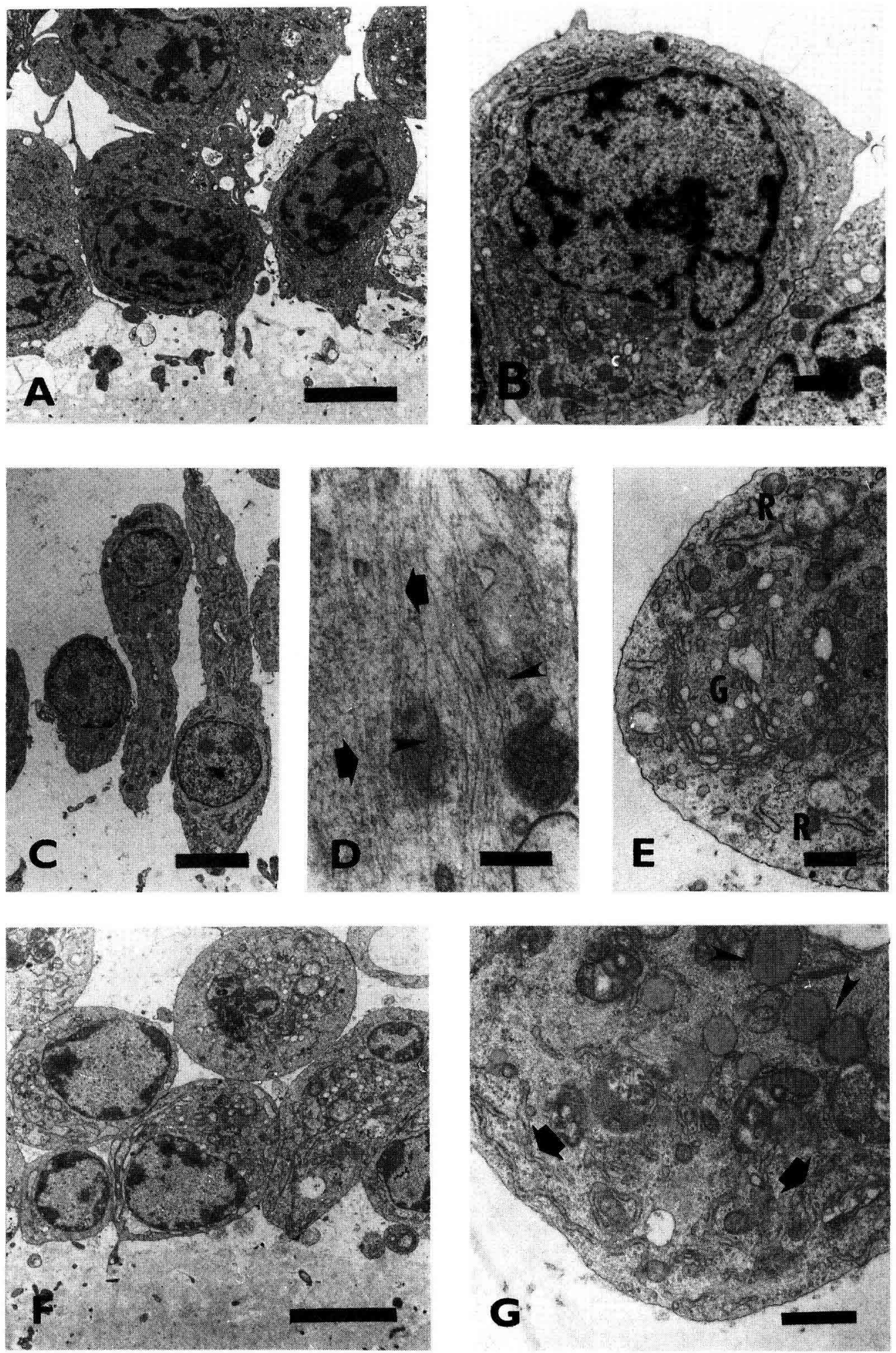
trast with the diffuse or dispersed Golgi complex in unstimulated cumulus cells (fig 2A) or cells cultured in the presence of cytochalasin B (fig 2C), the cells in expanded cumuli contained strongly labelled perinuclear caps of Golgi apparatus (fig 2B). The OCCs cultured for $24 \mathrm{~h}$ in $\mathrm{LH}$-containing medium with $20 \mu \mathrm{g} / \mathrm{ml}$ of cytochalasin B failed to expand and their cells retained a round shape and were devoid of microvilli and large projections (fig 1F). Randomly distributed rough endoplasmic reticulum, poorly developed Golgi and numerous lipid droplets were regularly observed in the cytoplasm of these cumulus cells (fig 1G).

\section{Distribution of actin microfilaments}

Rhodamine-phalloidin staining demonstrated a regular distribution of F-actin at the cell periphery of unstimulated cumulus cells (fig $3 \mathrm{~A}, \mathrm{~B})$. Following $6 \mathrm{~h}$ of culture, a time point coinciding with oocyte germinal vesicle breakdown, MF assembly occurred in the cytoplasm (fig $3 \mathrm{C}$ ). This caused extensive ruffling all along the plasma membranes and subsequent formation of large cellular projections (fig 3F). After $24 \mathrm{~h}$ of culture, the MFs were assembled in individual foci, coinciding with cytoplasmic projections (fig 3D). The addition of $5 \mu \mathrm{g} / \mathrm{ml}$ cytochalasinB to gonadotropin-supplemented medium was sufficient to block F-actin assembly in the OCCs cultured for 6-9 h. However, doses as high as $20 \mu \mathrm{g} / \mathrm{ml}$ of cytochalasin B were necessary to block cumulus expansion for $24 \mathrm{~h}$. This treatment caused the emergence of large actin bundles in the cytoplasm of cumulus cells (fig $3 E$ ).

\section{Microtubules and intermediate filaments}

Immunofluorescence revealed regular networks of MTs and IFs in the cytoplasm of unstimulated cumulus cells (figs 4A, 5A). Following culture in the presence of $\mathrm{LH}$, the organization of MTs and IFs reflected the alterations of cellular morphology. The IFs and MTs extended into the radial projections of cumulus cells within the expanded cumulus (figs $4 \mathrm{~B}, 5 \mathrm{~B}$ ). As was the case before stimulation, neither MTs nor IFs of corona radiata cells could be detected in the zona spanning projections (fig 4C). At the ultrastructural level, the MTs were also associated with the stacks of the Golgi apparatus (fig 4D). The clusters of lipid droplets, appearing as a consequence of $\mathrm{LH}$ stimulus, were regularly embedded in large bundles of IFs (fig $5 \mathrm{C}$ ).

The IFs were often closely associated with these droplets (fig 5D) and with the nuclear envelope (fig $5 \mathrm{E}$ ). The treatment with cytochalasin $\mathbb{Q}$ did not induce aggre-

Fig 1. Effect of cytochalasin $B$ on the expansion of cumulus oophorus and the elongattion and polarization of cumulus granulosa cells. (A) Cells in unstimulated OCCs (tO) are round and possess numerous small microvilli. Corona cells show frequent transzonal processes, bar $=5 \mu \mathrm{m}$. (B) The cytoplasm of such cells contains numerous mitochondria, RER and, Golgi, bar $=1 \mu \mathrm{m}$. (C) The cells in an expanded OCC, cultured for $24 \mathrm{~h}$ in the presence of $\mathrm{LH}$, form large radially oriented cytoplasmic projections, bar $=5 \mu \mathrm{m}$. (D) These projections are mainity occupied by longitudinally arranged microtubules (arrows) and intermediate filaments (arrowheads), $\mathrm{bar}=200 \mathrm{~nm}$. (E) The perinuclear region of an elongated cumulus cell is occupied by a well-developed Golgi apparatus (G) and $R E R(R)$, bar $=1 \mu \mathrm{m}$. (F) The cells in an OCC cultured for $24 \mathrm{~h}$ in LH-supplemented medium with $20 \mu \mathrm{g} / \mathrm{ml}$ of cytochalasin B are tightly packed and lack the microvilli and cytoplasmic projections, bar $=5 \mu \mathrm{m}$. (G) Treatment with cytochalasin $B$ did not affect the accumulation of lipid droplets (arrowheads) and randomized the distribution of RER (arrows) in the cytoplasm. The Golgi apparatus is not developed, bar $=1 \mu \mathrm{m}$. In micrographs $\mathbf{A}$, $\mathbf{C}$ and $\mathbf{F}$, the zona pellucida is located at the bottom of the micrograph. 

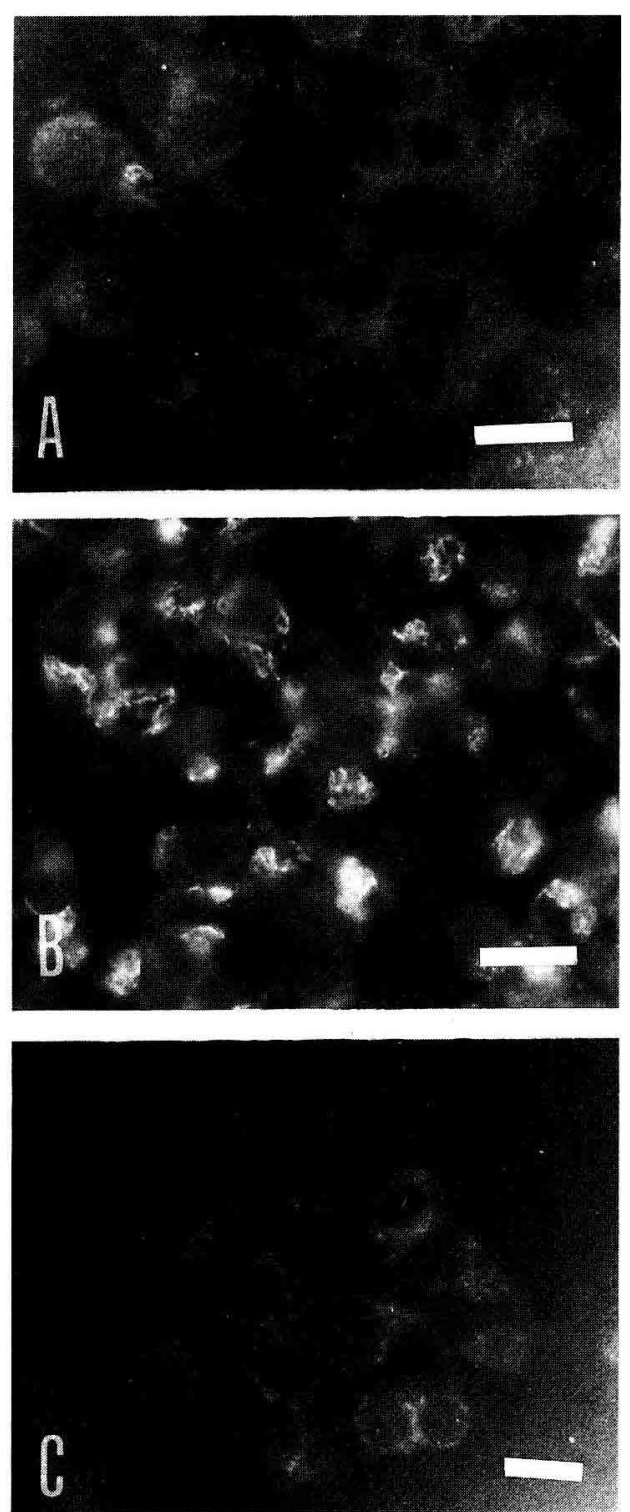

Fig 2. Distribution of the Golgi apparatus in bovine cumulus cells, demonstrated with CTR 433-antibody. (A) Diffuse labelling of the Golgi apparatus in unstimulated OCC (to). (B) Well-developed Golgi stacks are assembled in one pole of cumulus cell after $24 \mathrm{~h}$ of culture. (C) The addition of cytochalasin $\mathrm{B}$ to $\mathrm{LH}$-supplemented medium prevents the development and polarization of the Golgi apparatus, bar $=10 \mu \mathrm{m}$ for each micrograph. gates of MTs, or IFs as for MFs, and did not affect their association with organelles.

\section{DISCUSSION}

Cumulus expansion is the final step in the differentiation of cumulus granulosa cells (Paton and Collins, 1992), including the acceleration of extracellular matrix synthesis, cytoskeletal rearrangement, redistribution of gap junctions and volumetric enlargement of the cumulus oophorus. These changes result in the polarization and elongation of cumulus cells, allowing them to maintain intercellular communications inside the expanded cumulus oophorus (Allworth and Albertini, 1993; Sutovský et al, 1993).

Recently, we showed that the alterations in cumulus cell morphology and cumulus expansion are preceded by an extensive rearrangement of MFs in their cytoplasm, suggesting an important, if not crucial role of F-actin in the control of cumulus expansion (Śutovský et al, 1993). Whereas previous studies proposed that MFs could promote cumulus expansion by directing the endocytotic removal of cumulus cell gap junctions (Wert and Larsen, 1989; Chen et al, 1990), our recent results indicate that MFs are not directly associated with these junctions (Sutovský et al, 1993) and that cytochalasin treatment prevents cumulus expansion by suppressing membrane ruffling and subsequent polarization and elongation of cumulus cells (this study). The above data corroborate the studies on cultured granulosa cells, showing that gonadotropin-stimulation disrupts F-actin cytoskeleton, decreases the expression of actin and $\alpha$ actinin and elicits important alterations of cellular morphology and function (Ben Ze'ev and Amsterdam, 1989). On the contrary, we have not observed a direct effect of $\mathrm{LH}$ on IFs and MTs before cell elongation. Similarly, the gonadotropin stimulation of cultured granulosa cells does not affect the 

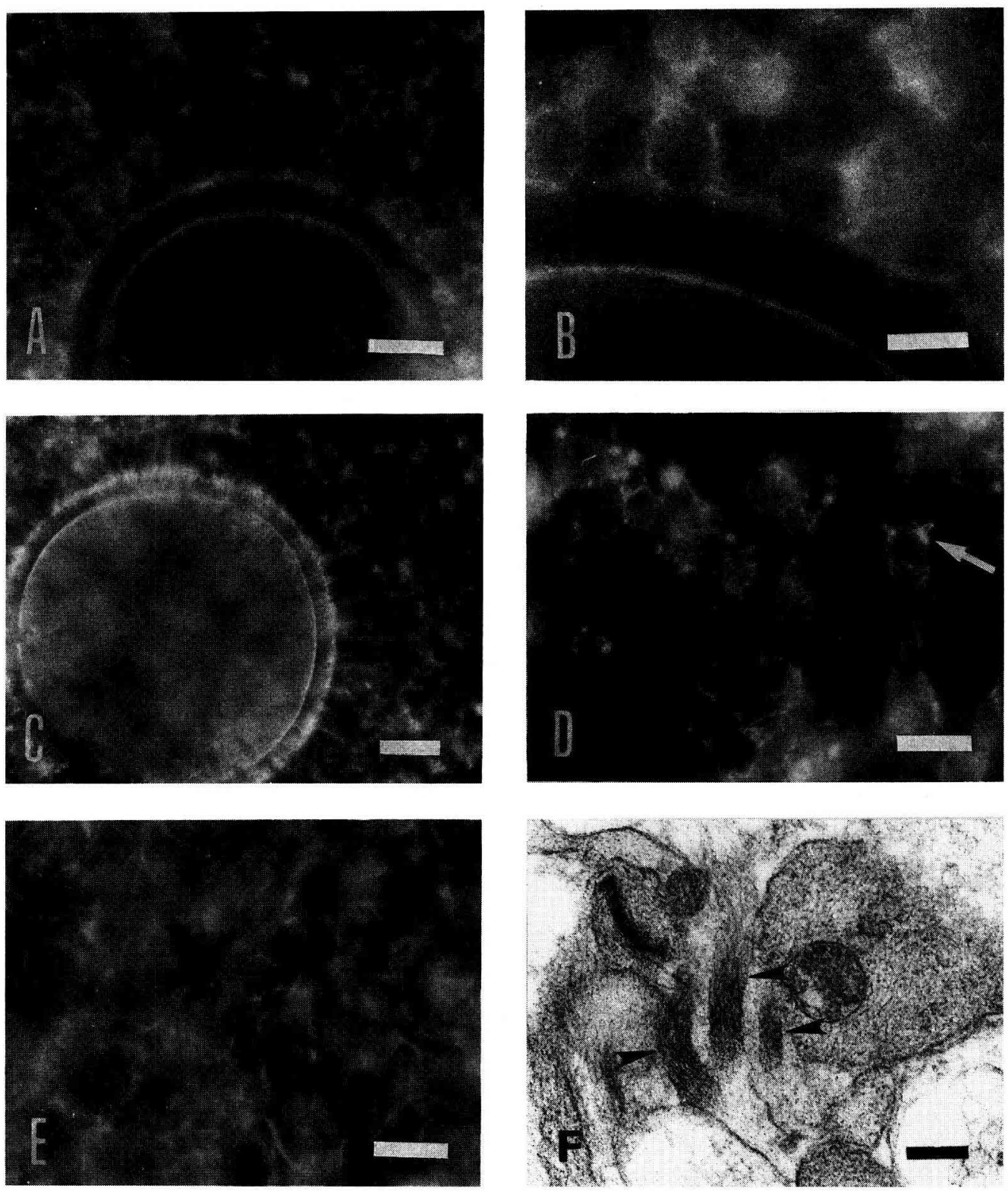

Fig 3. Dynamics of microfilaments during LH-induced cumulus expansion, demonstrated by rhodamine-phalloidin staining (A-E) and electron microscopy (F). (A) Regular distribution of F-actin in unstimulated OCC (10), bar $=20 \mu \mathrm{m}$. (B) Detail of an unstimulated OCC, showing uniform distribution of F-actin along the plasma membranes of cumulus cells. F-actin is also visible in zona-spanning projections of corona cells, bar $=10 \mu \mathrm{m}$. (C) Massive redistribution of F-actin occurs in cumulus cells within first $6 \mathrm{~h}$ culture in the presence of $\mathrm{LH}$, bar $=20 \mu \mathrm{m}$. (D) After $24 \mathrm{~h}$ of culture, the MFs are assembled in individual foci (arrow) at the foot of the cytoplasmic projections, bar $=20 \mu \mathrm{m}$. (E) Cytochalasin $B$ treatment causes dispersion of MFs and formation of stress fibre-like bundles in cumulus cell cytoplasm, bar $=10 \mu \mathrm{m}$. (F) Membrane ruffles in an OCC cultured for $6 \mathrm{~h}$ are loaded by large bundles of MFs (arrowheads), bar $=200 \mathrm{~nm}$. 

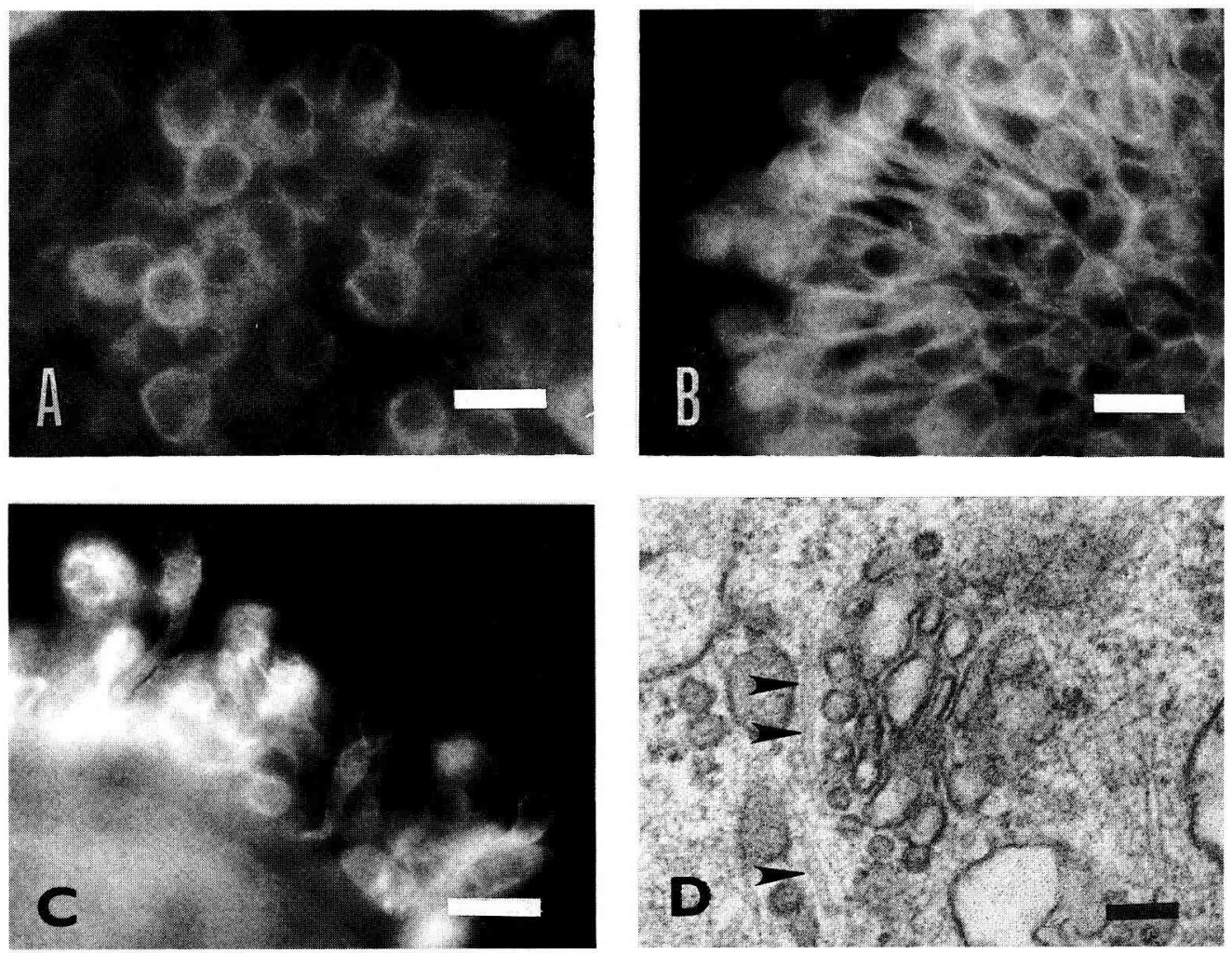

Fig 4. Immunofluorescent and uitrastructural localization of microtubules in bovine OCCs. The MTs form perinuclear networks in both unstimulated (A) and expanded (B) complexes. In $\mathbf{B}$, the long cytoplasmic projections also contain MTs. (C) No positivity to tubulin could be seen inside zona pellucida and periviteline space before (not shown) or after expansion. (D) At the ultrastructural level, the MTs (arrowheads) are frequently associated with the Golgi apparatus, bar $=20 \mu \mathrm{m}$ for micrographs A-C and $100 \mathrm{~nm}$ for $\mathrm{D}$.

expression of tubulin, vimentin and cytokeratin (Ben Ze'ev and Amsterdam, 1987). As well as cAMP-dependent protein kinase (PK-A), the LH receptor activates the phospholipase $\mathrm{C}$-dependent regulatory pathway (PK-C), which induces the assembly of Factin (Davis et al, 1986; Phatak et al, 1988). Moreover, LH-receptor distribution coincides with actin-loaded compartments of cytoplasmic membranes in granulosa cells (Amsterdam and Rotmensch, 1987). Altogether, these data strongly suggest that
$F$-actin mediates the response of cumulus cells to gonadotropins, influences the acquisition of final phenotype by these cells, and regulates cumulus expansion.

The generation of lipid droplets associated with IFs is a typical feature of steroidogenic cells, such as Leydig cells (Almahbodi et al, 1993) and granulosa cells (Silberzahn et al, 1985). Their accumulation in granulosa cells reflects the increased turnover of precursor lipid cholesterol during the $\mathrm{LH}$-induced conversion from estrogen 

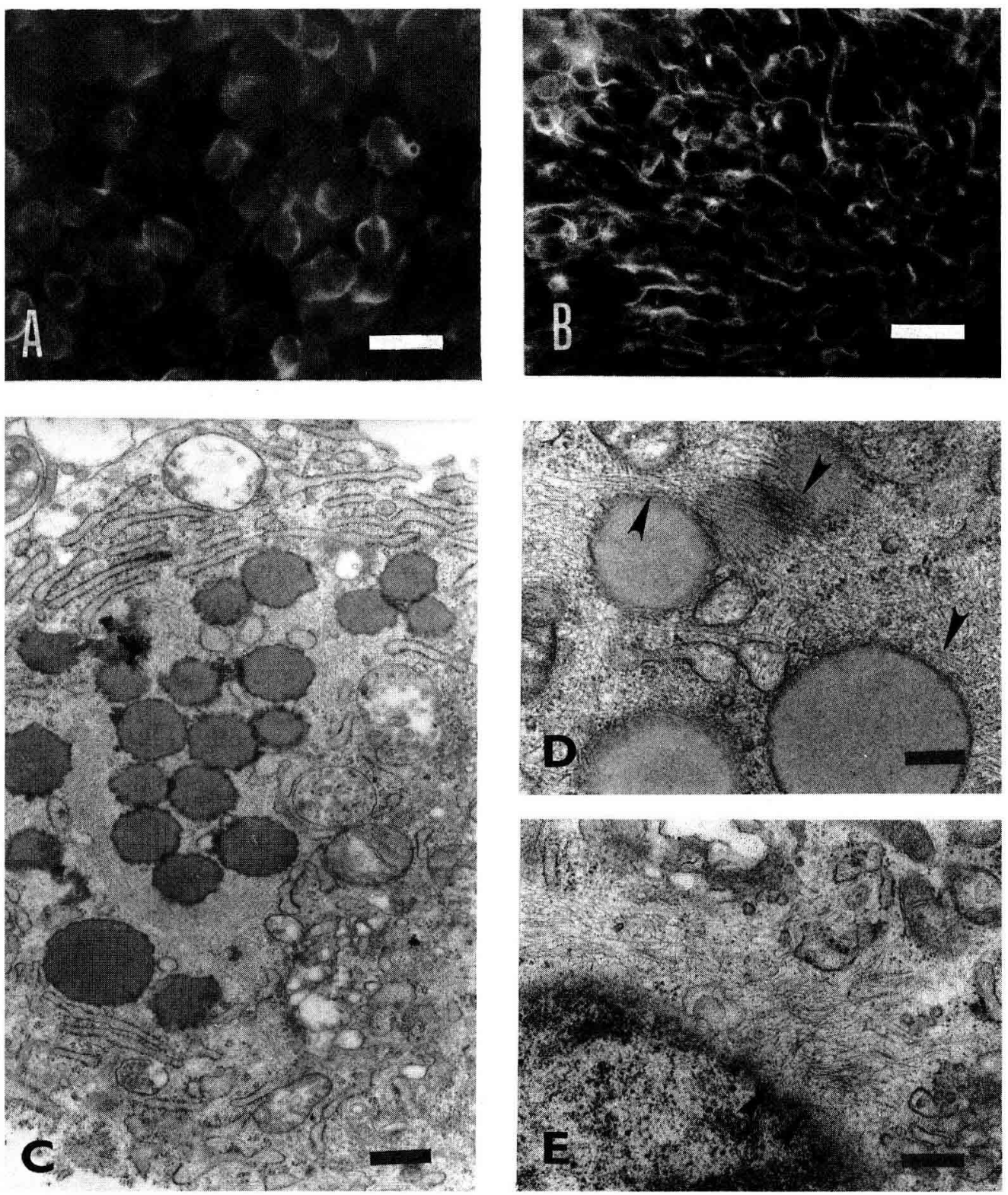

Fig 5. The distribution of IFs parallels that of MTs in cumulus cells of unstimulated (t0) $(A)$ and matured OCCs (B), bar $=20 \mu \mathrm{m}$ for $\mathbf{A}$ and $30 \mu \mathrm{m}$ for B. (C) Large clusters of lipid droplets are surrounded by bundles of IFs in cumulus cells of an OCC cultured for $24 \mathrm{~h}$ in LH-containing medium, bar $=500 \mathrm{~nm}$. (D) In such cells, the IFs (arrowheads) are closely associated with lipid droplets, bar $=200 \mathrm{~nm}$. (E) Sagittal section of the cell nucleus in an expanded OCC. Note apparent binding of IFs to the nuclear envelope (arrowheads), bar $=200 \mathrm{~nm}$. 
synthesis towards the secretion of progesterone (Collins et al, 1991). Intracellular transport of cholesterol was found to be vimentin dependent (Sarria et al, 1992). Experiments with microtubule stabilizing compounds such as taxol and colchicine (Carnegie et al, 1987) indicated that MTs control the cytoplasmic transport of lipid droplets. However, our study and others (Almahbodi and Hall, 1990) demonstrated that lipid droplets are exclusively associated with IFs. This discrepancy may be explained by the fact that the cytoplasmic networks of MTs and IFs are functionally linked and the disruption of MTs also damages the IF network (Skalli and Goldman, 1991). As well as IFs, the MFs also seem to participate in the regulation of granulosa cell steroidogenesis. Indeed, it was shown that cytochalasin treatment does not affect the generation of lipid droplets in LH-stimulated granulosa cells, but induces the secretion of progesterone by unstimulated ones (Ben Ze'ev and Amsterdam, 1987).

It is of general acceptance that MTs are involved in the polarization of Golgi apparatus and the control of cytoplasmic transport of Golgi vesicles (Vale, 1987). Since the close localization of Golgi with MTs has been described in bovine cumulus cells (this study) and in cultured human granulosa cells (Amsterdam et al, 1989), it seems likely that MTs determine the arrangement of cytoplasmic organelles and direct their reorganization in LH-stimulated granulosa cells.

We report here that gonadotropin stimulation promotes the development of Golgi and RER in cumulus cells. The functional significance of this event should be considered with regard to other events occurring at the time of cumulus expansion. In recent studies we showed that cumulus expansion in cattle is accompanied by the increased secretion of extracellular matrix glycoproteins laminin, type IV collagen and fibronectin, and by the anchorage of extracellular matrix at cytoplasmic membranes of cumulus cells (Sutovský et al, manuscript in preparation) The enzymatic machinery involved in the posttranslational modification and trafficking of glycoproteins has been localized in the RER and Golgi (Hirschberg and Snider, 1987; Hong and Tang, 1993). Thus, the polarization and increased size of the components of RER and Golgi apparatus in cumulus cells may be a prerequisite for the acceleration of glycoprotein secretion.

Taken together with the data discussed above, the present results suggest that individual cytoskeletal components fulfil spatially and temporally diversified functions throughout the gonadotropin-induced cumulus expansion in cattle. Although IFs and MTs participate in the determination of cell shape and in cytoplasmic movements of several organelles, F-actin seem to fulfil a crucial role in transduction of $\mathrm{LH}$ signals and in the control of the final differentiation of cumulus granulosa cells.

\section{ACKNOWLEDGMENTS}

The authors wish to thank $M$ Bornens and $V$ Viklický for their generous gift of antibodies. The technical assistance of S Delassale, J Degrolard and $V$ Pech are gratefully acknowledged. The work was partially supported by AID grant number $12061 \mathrm{E}$ and grant Z-503 from Czech Ministry of Economics. The stay of $P$ Sutovsky at INRA Jouyen-Josas was supported by scholarship from the CIES Paris, France.

\section{REFERENCES}

Allworth AE, Albertini DF (1993) Meiotic maturation in cultured bovine oocytes is accompanied by remodelling of the cumulus cell cytoskeleton. Dev Biol $158,101-112$

Almahbodi G, Hall PF (1990) The role of intermediate filaments of adrenal steroidogenesis. J Cell Sci 97 , 679-687

Almahbodi G, Williams LJ, Han XG, Hall PF (1993) Binding of lipid droplet and mitochondria to intermediate 
filaments in rat Leydig cells. J Reprod Fert 98, 209217

Amsterdam A, Rotmensch S (1987) Structure-function relationship during granulosa cell differentiation Endocrin Rev 8, 309-337

Amsterdam A, Rotmensch S, Ben Ze'ev A (1989) Coordinated regulation of morphological and biochemical differentiation in a steroidogenic cell: the granulosa cell model. Trends Biochem Sci 14, 377-382

Ben Ze'ev A, Amsterdam A (1987) In vitro regulation of granulosa cell differentiation. J Biol Chem 262, 53665376

Ben Ze'ev A, Amsterdam A (1989) Regulation of cytoskeletal protein organization and expression in human granulosa cells in response to gonadotropin regutreatment. Endocrinology 124, 1033-1041

Carnegie JA, Dardick I, Tsang BK (1987) Microtubules and gonadotropic regulation of granulosa cell steroidogenesis. Endocrinology 120, 819-828

Chen L, Wert SE, Hendrix M, Russel PT, Cannon M, Larsen WJ (1990) Hyaluronic acid synthesis and gap junction endocytosis are necessary for normal expansion of the cumulus mass. Mol Reprod Dev 26, 236-247

Collins W, Jurkovic D, Bourne T, Kurjak A, Campbell S (1991) Ovarian morphology, endocrine function and intra-follicular blood flow during the periovulatory period. Human Rep 6, 319-324

Davis JS, Weakland LL, West LA, Farese RV (1986) Luteinizing hormone stimulates the formation of inositol triphosphate and cyclic AMP in rat granulosa cells. Evidence for phospholipase-C-generated secand messengers in the action of luteinizing hormone. Biochem J 238, 567-604

Dekel N, Hillensjo Y, Kraicer PF (1979) Maturation effects of gonadotropins on the cumulus-oocyte complex of the rat. Biol Reprod 20, 191-197

Dráber P, Dráberova E, Zicconi D, Sellitto C, ViklickýV, Cappuccinelli P (1986) Heterogeneity of microtubules recognized by monoclonal antibodies to alpha tubulin. Eur J Cel/ Biol 41, 82-88

Eppig JJ (1980) Regulation of cumulus oophorus expansion by gonadotropins in vivo and in vitro. Biol Reprod $23,545-552$

Hirschberg CB, Snider MD (1987) Topography of glycosylation in the rough endoplasmic reticulum and Golgi apparatus. Ann Rev Biochem 46, 631-664
Hong W, Tang BL (1993) Protein trafficking along the exocytotic pathway. Bioassays 15, 231-238

Jasmin BJ, Cartaud J, Bornens M, Changeux JP (1989) Golgi apparatus in chick skeletal muscle: changes in its distribution during end plate development and after denervation. Proc Natl Acad Sci USA 86, 7218-7222

Larsen WJ, Wert SE, Brunner GD (1986) A dramatic loss of cumulus cell gap junctions is correlated with germinal vesicle breakdown in rat oocytes. Dev Biol $113,517-521$

Larsen WJ, Wert SE, Brunner GD (1987) Differential modulation of rat follicle cell gap junction populations at ovulation. Dev Biol 122, 61-71

Paton AC, Collins WP (1992) Differentiation processes of granulosa cells. Oxford Rev Reprod Biol 14, 168-223

Pavlok A, Lucas-Hahn A, Niemann H (1992) Fertilization and developmental competence of bovine oocytes derived from different categories of antral follicles. Mol Reprod Dev 31, 63-67

Phatak PD, Packman CH, Lichtman MA (1988) Protein kinase $\mathrm{C}$ modulates actin conformation in human $\mathrm{T}$ lymphocytes. J Immunol 141, 2929-2938

Sarria AJ, Panini SR, Evans M (1992) A functional role for vimentin intermediate filaments in the metabolism of lipoprotein-derived cholesterol in human SW-13 cells. J Biol Chem 27, 19455-19463

Silberzahn P, Almahdobi G, Dehennin L, Meroune A (1985) Estrogen metabolites in equine ovarian follicles: a chromatographic-mass spectrometric determination in relation to follicular ultrastructure and progestin content. J Steroid Biochem 22, 501-505

Skalli O, Goldman RD (1991) Recent insights into the assembly, dynamics, and function of intermediate filament networks. Cell Motil Cytoskelet 19, 67-79

Sutovský $P$, Fléchon JE, Fléchon B, Motlík J, Peynot $N$, Chesné $P$, Heyman $Y$ (1993) Dynamic changes of gap junctions and cytoskeleton during in vitro culture of cattle oocyte cumulus complexes. Biol Reprod $49,1277-1287$

Vale RD (1987) Intracellular transport using microtubulebased motors. Ann Rev Cell Biol 3, 373-378

Viklický V, Dráber P, Hasek J, Bártek J (1982) Production and characterization of monoclonal antitubulin antibody. Cell Biol Int Rep 6, 725-730

Wert SE, Larsen WJ (1989) Meiotic resumption and gap junction modulation in the cultured rat cumulus-oocyte complexes. Gamete Res 22, 143-162 